\title{
ANALISIS TINGKAT KEPUASAN MAHASISWA TERHADAP KINERJA DOSEN PROGRAM STUDI PENDIDIKAN AKUNTANSI FKIP UNIVERSITAS GALUH
}

\author{
Oleh: \\ D e d e h \\ Dosen Program Studi Pendidikan Akuntansi FKIP Universitas Galuh Ciamis \\ Jl. R.E. Martadinata No. 150, Ciamis 46274 Jawa Barat \\ Email:dedeh.akt15@gmail.com
}

\begin{abstract}
ABSTRAK
Program Studi selalu berusaha untuk memberikan pelayanan pendidikan yang sebaik-baiknya kepada para mahasiswa yang dibina dan dibimbingnya, sehingga mahasiswa dapat memberikan respon yang baik terhadap Program Studinya. Metode penelitian yang digunakan adalah metode Kuantitatif Deskriptif. Berdasarkan hasil penelitian dan pembahasan yang telah dilakukan dapat disimpulkan sebagai berikut: 1) Tingkat kepuasan mahasiswa Pendidikan Akuntansi terhadap kinerja dosen dalam pembelajaran yang ditinjau dari dimensi performance (penampilan) adalah sebagian besar responden 47,5\% menyatakan puas terhadap semua aspek pada dimensi ini; 2) ditinjau dari dimensi penguasaan materi perkuliahan adalah sebagian besar responden $65 \%$ menyatakan puas terhadap semua aspek pada dimensi ini; 3) ditinjau dari dimensi proses pembelajaran adalah sebagian besar responden 48,33\% menyatakan puas terhadap semua aspek ini; 4) ditinjau dari dimensi penggunaan media pembelajaran adalah sebagian besar responden $60 \%$ menyatakan puas terhadap semua aspek ini; 5) ditinjau dari dimensi pembelajaran dengan keterlibatan mahasiswa adalah sebagian besar responden $62,5 \%$ menyatakan puas terhadap semua aspek ini; 6) ditinjau dari dimensi penilaian hasil belajar mahasiswa adalah sebagian besar responden 50\% menyatakan puas terhadap semua aspek ini; 7) ditinjau dari dimensi penutup adalah sebagian besar responden $60 \%$ menyatakan cukup puas terhadap semua aspek ini.
\end{abstract}

Kata Kunci: Kepuasan Mahasiswa dan kinerja dosen

\section{PENDAHULUAN}

Persaingan untuk memasuki dunia kerja dan sangat tingginya biaya pendidikan, membuat masyarakat yang akan melanjutkan pendidikannya keperguruan tinggi akan selektif dalam memilih dan menetapkan Perguruan Tinggi sebagai pilihannya. Persaingan yang semakin ketat antara institusi dengan institusi lain, membuat Fakultas Keguruan dan Ilmu Pendidikan khususnya Program Studi Pendidikan Akuntansi untuk tetap memperhatikan kualitas pendidikan, baik buruknya kualitas pendidikannya tergantung dengan kinerja dosen dalam pembelajaran.

Untuk dapat bersaing dengan perguruan tinggi lain salah satu faktor yang perlu diperhatikan adalah kepuasan belajar mahasiswa terhadap Universitasnya. Ujung tombak dari kepuasan mahasiswa adalah kualitas dosennya. Sebagai pihak yang melaksanakan proses produksi atau menyampaikan jasa pendidikan kepada para mahasiswa. Kualitas dosen dapat dinilai berdasarkan kinerja dosen yang dirasakan mahasiswa selama menjalankan proses pendidikan dan pembelajaran.
Menurut Rivai, (2005: 15) Kinerja adalah kesediaan seseorang atau kelompok orang untuk melakukan sesuatu kegiatan dan menyempurnakannya sesuai dengan tanggung jawabnya dengan hasil seperti yang diharapkan. Dari pengertian di atas bisa dilihat bahwa kualitas pendidikan yang baik apabila dosen melakukan kegiatan mengajarnya sesuai dengan tanggung jawab dengan hasil yang diharapkan mahasiswa.

Harapan mahasiswa sebagai pemakai jasa atau konsumen Program Studi, berharap kinerja dosen sebagai penyampai jasa pendidikan menjalankan proses pendidikan secara maksimal, seperti menggunakan metode yang menarik dalam proses pembelajarannya, dosen yang hadir tepat waktu, melaksanakan UTS dan UAS tepat waktu, serta pengembalian lembar jawaban ujian kepada mahasiswa.

Kinerja dosen yang baik, apabila dosen menjalankan perkuliahan sesuai dengan Standar mutu perkuliahan. Dimana dalam suatu perkuliahan dosen memiliki GBPP, Silabus SAP, Kontrak perkuliahan, materi perkuliahan, media perkuliahan, Bahan Ajar perkuliahan, 
arsip soal kuis, soal UTS, UAS dan tugas telah tersedia dalam bentuk tercetak.

Agar dapat memuaskan mahasiswa sebagai konsumen, maka Program Studi Pendidikan Akuntansi Fakultas Keguruan dan Ilmu Pendidikan perlu menerapkan kinerja dosen yang sesuai dengan standar mutu perkuliahan, sehingga kepuasan mahasiswa sebagai pelanggan terpenuhi.

Menurut Kotler (2000: 57) kepuasan adalah perasaan senang atau kecewa seseorang yang berasal dari perbandingan antara kesannya terhadap kinerja (hasil) sesuatu produk dengan harapannya. Menurut Tjiptono (2004: 146) kepuasan dan ketidakpuasan pelanggan adalah respon pelanggan terhadap evaluasi ketidaksesuaian yang dirasakan antara harapan sebelumnya dan kinerja aktual produk yang dirasakan setelah pemakaiannya.

Berdasarkan definisi tersebut dapat disimpulkan kepuasan konsumen merupakan respon yang dirasakan oleh konsumen terhadap barang atau jasa yang dirasakannya setelah pemakaiannya. Dengan demikian, mahasiswa sebagai orang yang mengambil manfaat dari jasa yang diberikan dari Program Studi itu sendiri. Program Studi selalu berusaha untuk memberikan pelayanan pendidikan yang sebaikbaiknya kepada para mahasiswa yang dibina dan dibimbingnya, sehingga mahasiswa dapat memberikan respon yang baik terhadap Program Studinya. Tapi sebaliknya mahasiswa tidak akan merasa puas jika pelayanan atau kinerja di tempat mereka menimba ilmu tidak sesuai dengan harapannya. Oleh karena itu perguruan tinggi atau lembaga pendidikan harus bisa memberikan pelayanan yang berkualitas kepada mahasiswa sesuai yang diharapkan oleh mahasiswa sebagai konsumen atau pemakai jasa pendidikan.

Untuk pengembangan kualitas kedepannya sesuai dengan Visi Program Studi bahwa terwujudnya Program Studi Pendidikan Akuntansi yang unggul dan berdaya saing global pada tahun 2030, maka perlunya untuk meningkatkan mutu perkuliahan dosen dari setiap komponen untuk memberikan kepuasan terhadap mahasiswanya.

\section{METODE PENELITIAN}

Penelitian ini dilakukan di Program Studi Pendidikan Akuntansi Fakultas Keguruan dan Ilmu Pendidikan Universitas Galuh Ciamis.Waktu penelitian ini dilakukan pada bulan April sampai Juli 2017. Populasi penelitian ini adalah mahasiswa Program Studi Pendidikan Akuntansi angkatan 2015 yang berjumlah 99 orang dan sampel yang diambil berjumlah 20 orang. Adapun data yang digunakan dalam penelitian ini adalah data primer yang diperoleh melalui penelitian di lapangan dengan cara penyebaran kuesioner kepada responden.

Teknik pengumpulan data dalam penelitian ini dilakukan dengan berupa angket. Penelitian ini menganalisis satu variabel yaitu kepuasan mahasiswa yang di ukur dengan lima dimensi untuk mengukur kepuasan yang menjadi penentu mutu pelayanan jasa. Untuk mempermudah pengumpulan data dan tidak terjadi kekeliruan dalam mengartikan objek penelitian, maka variable yang akan diuji dalam penelitian adalah kepuasan mahasiswa yang diukur dengan tujuh dimensi yang menjadi penentu mutu pelayanan jasa yang diterapkan dalam lembaga pendidikan yaitu:

1. Performance (Penampilan), yaitu bentuk fisik yang ada pada dosen saat melaksanakan proses perkuliahan yang bisa dirasakan serta dapat dilihat langsung oleh mahasiswa. Indikator penilaiannya meliputi: dosen berpakaian sopan, berpenampilan menarik dan meyakinkan, bersikap baik dan profesional.

2. Penguasaan materi perkuliahan, yaitu kemampuan dosen untuk memberikan pelayanan yang dijanjikan dengan tepat dan akurat kepada mahasiswa. Indikator penilaiannya meliputi: menguasai materi dan keterkaitan dengan realita kehidupan, menggunakan komunikasi interaktif, menggunakan unsur-unsur kebahasaan, menggunakan struktur logika, ketepatan materi dalam proses belajar mengajar.

3. Proses pembelajaran, yaitu kegiatan pelayanan pendidikan kepada mahasiswa yang mencakup proses belajar mengajar serta pembinaan, pelatihan dan pembimbingan. Indikator penilaiannya meliputi: melaksanakan pembelajaran sesuai SAP, melaksanakan pembelajaran yang sesuai dengan tingkat perkembangan, melaksanakan pembelajaran yang memungkinkan tumbuhnya kebiasaan positif, menguasai kelas, melaksanakan pembelajaran tepat waktu sesuai jadwal, melaksanakan pembelajaran sesuai waktu yang telah dialokasikan.

4. Penggunaan media pembelajaran, yaitu bukti kekreatifan dan keterampilan dosen dalam 
menggunakan media pembelajaran. Indikator penilaiannya adalah keterampilan dalam menggunakan media pembelajaran dan keterlibatan mahasiswa dalam menggunakan media pembelajaran.

5. Pembelajaran dengan keterlibatan mahasiswa, yaitu sikap dan perilaku dosen selama berinteraksi dengan mahasiswanya. Indikator penilaiannya meliputi: menumbuhkan partisipasi aktif mahasiswa, memfasilitasi interaksi desen-mahasiswa, memfasilitasi interaksi mahasiswa-mahasiswa, sikap terbuka terhadap partisipasi aktif mahasiswa.
6. Penilaian hasil belajar, yaitu penilaian yang dilaksanakan di akhir sebagai evaluasi akhir proses pembelajaran yang dilakukan secara obyektif. Indikator penilaiannya meliputi: penilaian akhir secara obyektif.

7. Penutup, yaitu kegiatan membuat rangkuman materi pembelajaran dengan melibatkan mahasiswa yang dilaksanakan di akhir proses pembelajaran. Indikator penilaiannya meliputi membuat rangkuman pembelajaran dengan melibatkan mahasiswa.

\section{HASIL PENELITIAN DAN PEMBAHASAN \\ Hasil Penelitian}

Berdasarkan data-data yang diperoleh berkaitan dengan tingkat kepuasan mahasiswa terhadap kinerja dosen dalam pembelajaran pada Program Studi Pendidikan Akuntansi Universitas Galuh maka berikut ini disajikan hasil penelitian sebagai berikut:

\section{Performance (Penampilan)}

Performance (Penampilan), yaitu bentuk fisik yang ada pada dosen saat melaksanakan proses perkuliahan yang bisa dirasakan serta dapat dilihat langsung oleh mahasiswa. Indikator penilaiannya meliputi: dosen berpakaian sopan, berpenampilan menarik dan meyakinkan, bersikap baik dan profesional.

Berdasarkan hasil penelitian pada mahasiswa pendidikan akuntansi angkatan 2015 dapat dilihat distribusi frekuensi kepuasan mahasiswa pendidikan akuntansi terhadap kinerja dosen pada dimensi Performance (penampilan).

Tabel 1. Distribusi frekuensi kepuasan mahasiswa terhadap kinerja dosen pada dimensi Performance (penampilan)

Persentase Capaian
\begin{tabular}{|l|l|l|l|l|l|l|l|l|}
\hline \multirow{2}{*}{ No } & \multicolumn{1}{|c|}{ Pernyataan } & \multicolumn{2}{c|}{ Persentase Nilai yang Dicapai (\%) } & Jml (\%) \\
\cline { 3 - 9 } & & SP & P & CP & KP & TP & \\
\hline A & Performance (Penampilan) & \multicolumn{7}{|l|}{} \\
\hline 1 & Berpakaian sopan & 40 & 50 & 10 & 0 & 0 & 100 \\
\hline 2 & Bersikap baik dan professional & 35 & 45 & 20 & 0 & 0 & 100 \\
\hline & Jumlah & 75 & 95 & 30 & 0 & 0 & 200 \\
\hline & Rata-rata & $\mathbf{3 7 . 5}$ & $\mathbf{4 7 . 5}$ & $\mathbf{1 5}$ & $\mathbf{0}$ & $\mathbf{0}$ & $\mathbf{1 0 0}$ \\
\hline
\end{tabular}

\section{Keterangan:}

$\begin{array}{llllll}\text { SP } & \text { : Sangat Puas, } & \text { P } & \text { : Puas, } & \text { CP } & \text { : Cukup Puas, } \\ \text { KP } & \text { : Kurang Puas, } & \text { TP } & \text { : Tidak puas } & & \end{array}$

Berdasarkan tabel di atas dapat diketahui bahwa dari keseluruhan aspek pada dimensi Performance (penampilan) ternyata sebagian responden yaitu sebanyak 47,5\% menyatakan mereka merasa puas terhadap kinerja dosen pada dimensi Performance (penampilan). Dan 37,5\% serta 15\% saja yang menyatakan sangat puas dan cukup puas terhadap kinerja dosen pada dimensi Performance (penampilan). Hal ini berarti bahwa penampilan dan cara berpakaian dosen serta berikap yang baik dan profesional kepada mahasiswa telah terlaksana dengan baik, walaupun demikian masih perlu untuk ditingkatkan lebih baik lagi yang berkaitan dengan aspek di atas. 


\section{Penguasaan materi perkuliahan}

Penguasaan materi perkuliahan, yaitu kemampuan dosen untuk memberikan pelayanan yang dijanjikan dengan tepat dan akurat kepada mahasiswa. Indikator penilaiannya meliputi: menguasai materi dan keterkaitan dengan realita kehidupan, menggunakan komunikasi interaktif, menggunakan unsur-unsur kebahasaan, menggunakan struktur logika, ketepatan materi dalam proses belajar mengajar.

Tabel 2. Distribusi frekuensi kepuasan mahasiswa terhadap kinerja dosen pada dimensi penguasaan materi perkuliahan.

\begin{tabular}{|c|c|c|c|c|c|c|c|}
\hline \multirow{2}{*}{ No } & \multirow{2}{*}{ Pernyataan } & \multicolumn{5}{|c|}{ Persentase Nilai yang Dicapai (\%) } & \multirow[t]{2}{*}{$\operatorname{Jml}(\%)$} \\
\hline & & SP & $\mathbf{P}$ & $\mathbf{C P}$ & $\mathbf{K P}$ & TP & \\
\hline B & \multicolumn{7}{|c|}{ Penguasaan Materi Perkuliahan } \\
\hline 1 & $\begin{array}{l}\text { Menguasai materi dan } \\
\text { keterkaitan dengan realita } \\
\text { Kehidupan }\end{array}$ & 20 & 60 & 20 & 0 & 0 & 100 \\
\hline 2 & $\begin{array}{l}\text { Menggunakan komunikasi } \\
\text { interaktif }\end{array}$ & 15 & 70 & 15 & 0 & 0 & 100 \\
\hline 3 & $\begin{array}{l}\text { Menggunakan unsur-unsur } \\
\text { kebahasaan }\end{array}$ & 25 & 60 & 15 & 0 & 0 & 100 \\
\hline 4 & Menggunakan struktur logika & 20 & 70 & 10 & 0 & 0 & 100 \\
\hline & Jumlah & 80 & 260 & 60 & 0 & 0 & 400 \\
\hline & Rata-rata & 20 & 65 & 15 & 0 & 0 & 100 \\
\hline
\end{tabular}

Keterangan:

$\begin{array}{llllll}\text { SP } & \text { : Sangat Puas, } & \text { P } & \text { : Puas, } & \text { CP } & \text { : Cukup Puas, } \\ \text { KP } & \text { : Kurang Puas, } & \text { TP } & \text { : Tidak puas }\end{array}$

Berdasarkan hasil penelitian pada mahasiswa pendidikan akuntansi angkatan 2015 dapat dilihat distribusi frekuensi kepuasan mahasiswa pendidikan akuntansi terhadap kinerja dosen pada dimensi penguasaan materi perkuliahan. Berdasarkan tabel di atas dapat diketahui bahwa dari keseluruhan aspek pada dimensi penguasaan materi perkuliahan ternyata sebagian responden yaitu sebanyak $65 \%$ menyatakan mereka merasa puas terhadap kinerja dosen pada dimensi penguasaan materi perkuliahan. Dan $20 \%$ serta $15 \%$ saja yang menyatakan sangat puas dan cukup puas terhadap kinerja dosen pada dimensi penguasaan materi perkuliahan. Hal ini berarti bahwa penguasaan materi dan keterkaitan dengan realita kehidupan, penggunaan komunikasi interaktif, penggunaan unsur-unsur kebahasaan, penggunaan struktur logika, ketepatan materi dalam proses belajar mengajar, kepada mahasiswa telah terlaksana dengan baik, namun demikian masih perlu ditingkatkan lebih baik lagi yang berkaitan dengan aspek di atas.

\section{Proses Pembelajaran}

Proses pembelajaran, yaitu kegiatan pelayanan pendidikan kepada mahasiswa yang mencakup proses belajar mengajar serta pembinaan, pelatihan dan pembimbingan. Indikator penilaiannya meliputi: melaksanakan pembelajaran sesuai SAP, melaksanakan pembelajaran yang sesuai dengan tingkat perkembangan, melaksanakan pembelajaran yang memungkinkan tumbuhnya kebiasaan positif, menguasai kelas, melaksanakan pembelajaran tepat waktu sesuai jadwal, melaksanakan pembelajaran sesuai waktu yang telah dialokasikan.

Berdasarkan hasil penelitian pada mahasiswa pendidikan akuntansi angkatan 2015 dapat dilihat distribusi frekuensi kepuasan mahasiswa pendidikan akuntansi terhadap kinerja dosen pada dimensi proses pembelajaran. 
Tabel 2. Distribusi frekuensi kepuasan mahasiswa terhadap kinerja dosen pada dimensi penguasaan materi perkuliahan

\begin{tabular}{|c|c|c|c|c|c|c|c|}
\hline \multirow{2}{*}{ No } & \multirow{2}{*}{ Pernyataan } & \multicolumn{5}{|c|}{ Persentase Nilai yang Dicapai (\%) } & \multirow[t]{2}{*}{$\operatorname{Jml}(\%)$} \\
\hline & & SP & $\mathbf{P}$ & $\mathbf{C P}$ & KP & $\mathbf{T P}$ & \\
\hline $\mathbf{C}$ & \multicolumn{7}{|l|}{ Proses Pembelajaran } \\
\hline 1 & $\begin{array}{l}\text { Melaksanakan pembelajaran } \\
\text { sesuai SAP }\end{array}$ & 0 & 65 & 35 & 0 & 0 & 100 \\
\hline 2 & $\begin{array}{l}\text { Melaksanakan pembelajaran } \\
\text { yang sesuai dengan tingkat } \\
\text { perkembangan }\end{array}$ & 15 & 50 & 35 & 0 & 0 & 100 \\
\hline 3 & $\begin{array}{l}\text { Melaksanakan pembelajaran } \\
\text { yang memungkinkan } \\
\text { tumbuhnya kebiasaan positif }\end{array}$ & 20 & 40 & 40 & 0 & 0 & 100 \\
\hline 4 & Menguasai kelas & 20 & 45 & 20 & 0 & 0 & 85 \\
\hline 5 & $\begin{array}{l}\text { Melaksanakan pembelajaran } \\
\text { tepat waktu sesuai Jadwal }\end{array}$ & 15 & 40 & 40 & 5 & 0 & 100 \\
\hline 6 & $\begin{array}{l}\text { Melaksanakan pembelajaran } \\
\text { sesuai waktu yang telah } \\
\text { dialokasikan }\end{array}$ & 15 & 50 & 35 & 0 & 0 & 100 \\
\hline & Jumlah & 85 & 290 & 205 & 5 & 0 & 585 \\
\hline & Rata-rata & 14.1667 & 48.33 & 34.1667 & $\mathbf{0 . 8 3 3 3}$ & 0 & 97.5 \\
\hline
\end{tabular}

Keterangan:

$\begin{array}{llllll}\text { SP } & \text { : Sangat Puas, } & \text { P } & \text { : Puas, } & \text { CP } & \text { : Cukup Puas, } \\ \text { KP } & \text { : Kurang Puas, } & \text { TP } & \text { : Tidak puas } & & \end{array}$

Berdasarkan tabel di atas dapat diketahui bahwa dari keseluruhan aspek pada dimensi proses pembelajaran ternyata sebagian responden yaitu sebanyak $48,33 \%$ menyatakan mereka merasa puas dan $14,167 \%$ menyatakan sangat puas terhadap kinerja dosen pada dimensi proses pembelajaran. Dan $34,167 \%$ serta $0,8333 \%$ saja yang menyatakan cukup puas dan kurang puas terhadap kinerja dosen pada dimensi proses pembelajaran. Hal ini berarti bahwa kesigapan dosen dalam menjalankan proses pembelajaran, menumbuhkan minat dan semangat, menumbuhkan suasana belajar yang menyenangkan, telah terlaksana dengan baik, namun demikian oleh karena masih ada mahasiswa yang merasakan kurang puas maka kepada dosen Program Studi Pendidikan Akuntansi masih perlu ditingkatkan yang berkaitan dengan aspek di atas terutama dalam pelaksanaan pembelajaran tepat waktu sesuai jadwal.

\section{Penggunaan Media Pembelajaran}

Penggunaan media pembelajaran, yaitu bukti kekreatifan dan keterampilan dosen dalam menggunakan media pembelajaran. Indikator penilaiannya adalah keterampilan dalam menggunakan media pembelajaran dan keterlibatan mahasiswa dalam menggunakan media pembelajaran. Berdasarkan hasil penelitian pada mahasiswa pendidikan akuntansi angkatan 2015 dapat dilihat distribusi frekuensi kepuasan mahasiswa pendidikan akumtansi terhadap kinerja dosen pada dimensi penggunaan media pembelajaran. 
Tabel 4. Distribusi frekuensi kepuasan mahasiswa terhadap kinerja dosen pada dimensi penggunaan media pembelajaran

\begin{tabular}{|c|c|c|c|c|c|c|c|}
\hline \multirow{2}{*}{ No } & \multirow{2}{*}{ Pernyataan } & \multicolumn{5}{|c|}{ Persentase Nilai yang Dicapai (\%) } & \multirow{2}{*}{$\operatorname{Jml}(\%)$} \\
\hline & & SP & $\mathbf{P}$ & $\mathbf{C P}$ & KP & $\mathbf{T P}$ & \\
\hline D & \multicolumn{7}{|l|}{ Penggunaan Media Pembelajaran } \\
\hline 1 & $\begin{array}{l}\text { Keterampilan dalam menggunakan } \\
\text { media Pembelajaran }\end{array}$ & 5 & 75 & 20 & 0 & 0 & 100 \\
\hline 2 & $\begin{array}{l}\text { Keterlibatan mahasiswa dalam } \\
\text { menggunakan media pembelajaran }\end{array}$ & 15 & 45 & 40 & 0 & 0 & 100 \\
\hline & Jumlah & 20 & 120 & 60 & 0 & 0 & 200 \\
\hline & Rata-rata & 10 & 60 & 30 & $\mathbf{0}$ & $\mathbf{0}$ & 100 \\
\hline
\end{tabular}

\section{Keterangan:}

$\begin{array}{llllll}\text { SP } & \text { : Sangat Puas, } & \text { P } & \text { : Puas, } & \text { CP } & \text { : Cukup Puas, } \\ \text { KP } & \text { : Kurang Puas, } & \text { TP } & \text { : Tidak puas }\end{array}$

Berdasarkan tabel di atas dapat diketahui bahwa dari keseluruhan aspek pada dimensi penggunaan media pembelajaran ternyata sebahagian responden yaitu sebanyak $60 \%$ menyatakan mereka merasa puas terhadap kinerja dosen pada dimensi penggunaan media pembelajaran. Dan hanya 10\% dan 30\% saja yang menyatakan sangat puas dan cukup puas terhadap kinerja dosen pada dimensi penggunaan media pembelajaran. Hal ini berarti bahwa dosen memiliki keterampilan dalam penggunaan media pembelajaran dan keterlibatan mahasiswa dalam menggunakan media pembelajaran telah terlaksana dengan baik, namun demikian kepada dosen Program Studi Pendidikan Akuntansi masih perlu ditingkatkan yang berkaitan dengan aspek di atas.

\section{Pembelajaran Dengan Keterlibatan Mahasiswa}

Pembelajaran dengan keterlibatan mahasiswa, yaitu sikap dan perilaku dosen selama berinteraksi dengan mahasiswanya. Indikator penilaiannya meliputi: menumbuhkan partisipasi aktif mahasiswa, memfasilitasi interaksi desen-mahasiswa, memfasilitasi interaksi mahasiswa-mahasiswa, sikap terbuka terhadap partisipasi aktif mahasiswa.

Berdasarkan hasil penelitian pada mahasiswa pendidikan akuntansi angkatan 2015 dapat dilihat distribusi frekuensi kepuasan mahasiswa pendidikan akuntansi terhadap kinerja dosen pada aspek pembelajaran dengan keterlibatan mahasiswa.

Tabel 5. Distribusi frekuensi kepuasan mahasiswa terhadap kinerja dosen pada aspek pembelajaran dengan keterlibatan mahasiswa

\begin{tabular}{|c|c|c|c|c|c|c|c|}
\hline \multirow{2}{*}{ No } & \multirow{2}{*}{ Pernyataan } & \multicolumn{5}{|c|}{ Persentase Nilai yang Dicapai (\%) } & \multirow{2}{*}{$\mathbf{J m l}$} \\
\hline & & SP & $\mathbf{P}$ & $\mathbf{C P}$ & KP & $\mathbf{T P}$ & \\
\hline $\mathbf{E}$ & \multicolumn{7}{|l|}{$\begin{array}{l}\text { Pembelajaran dengan } \\
\text { Keterlibatan Mahasiswa }\end{array}$} \\
\hline 1 & $\begin{array}{l}\text { Menumbuhkan partisipasi aktif } \\
\text { mahasiswa }\end{array}$ & 10 & 65 & 25 & 0 & 0 & 100 \\
\hline 2 & $\begin{array}{l}\text { Memfasilitasi interaksi dosen- } \\
\text { mahasiswa }\end{array}$ & 10 & 60 & 30 & 0 & 0 & 100 \\
\hline 3 & $\begin{array}{l}\text { Memfasilitasi interaksi mahasiswa- } \\
\text { mahasiswa }\end{array}$ & 10 & 65 & 25 & 0 & 0 & 100 \\
\hline 4 & $\begin{array}{l}\text { Sikap terbuka terhadap partisipasi } \\
\text { aktif mahasiswa }\end{array}$ & 35 & 60 & 5 & 0 & 0 & 100 \\
\hline & Jumlah & 65 & 250 & 85 & 0 & 0 & 400 \\
\hline & Rata-rata & 16.25 & 62.5 & 21.25 & $\mathbf{0}$ & $\mathbf{0}$ & 100 \\
\hline
\end{tabular}




\section{Keterangan:}

$\begin{array}{llllll}\text { SP } & \text { : Sangat Puas, } & \text { P } & \text { : Puas, } & \text { CP } & \text { : Cukup Puas, } \\ \text { KP } & \text { : Kurang Puas, } & \text { TP } & \text { : Tidak puas } & & \end{array}$

Berdasarkan tabel di atas dapat diketahui bahwa dari keseluruhan aspek pada dimensi pembelajaran dengan keterlibatan mahasiswa ternyata sebagian responden yaitu sebanyak $62,5 \%$ menyatakan mereka merasa puas terhadap kinerja dosen pada dimensi pembelajaran dengan keterlibatan mahasiswa. Dan hanya $16,25 \%$ dan $21,25 \%$ saja yang menyatakan sangat puas dan cukup puas terhadap kinerja dosen pada dimensi pembelajaran dengan keterlibatan mahasiswa. Hal ini berarti bahwa kesediaan dosen membantu mahasiswa, memberikan perhatian terhadap kemajuan mahasiswa, dan memberikan masukan/pujian kepada mahasiswa, telah terlaksana dengan baik, namun demikian kepada dosen Program Studi Pendidikan Akuntansi masih perlu ditingkatkan yang berkaitan dengan aspek di atas.

\section{Penilaian Hasil Belajar}

Penilaian hasil belajar, yaitu penilaian yang dilaksanakan di akhir sebagai evaluasi akhir proses pembelajaran yang dilakukan secara obyektif. Indikator penilaiannya meliputi: penilaian akhir secara obyektif.

Berdasarkan hasil penelitian pada mahasiswa pendidikan akuntansi angkatan 2015 dapat dilihat distribusi frekuensi kepuasan mahasiswa pendidikan akuntansi terhadap kinerja dosen pada aspek penilaian hasil belajar.

Tabel 6. Distribusi frekuensi kepuasan mahasiswa terhadap kinerja dosen pada aspek penilaian hasil belajar

\begin{tabular}{|c|c|c|c|c|c|c|c|}
\hline \multirow{2}{*}{ No } & \multirow{2}{*}{ Pernyataan } & \multicolumn{5}{|c|}{ Persentase Nilai yang Dicapai (\%) } & \multirow{2}{*}{$\begin{array}{l}\mathrm{Jml} \\
(\%)\end{array}$} \\
\hline & & SP & $\mathbf{P}$ & CP & KP & $\mathbf{T P}$ & \\
\hline $\mathbf{F}$ & Penilaian Hasil Belajar & & & & & & \\
\hline 1 & Penialaian akhir secara obyektif & 35 & 50 & 15 & 0 & 0 & 100 \\
\hline
\end{tabular}

\section{Keterangan:}

$\begin{array}{llllll}\text { SP } & \text { : Sangat Puas, } & \text { P } & \text { : Puas, } & \text { CP } & \text { : Cukup Puas, } \\ \text { KP } & \text { : Kurang Puas, } & \text { TP } & \text { : Tidak puas } & & \end{array}$

Berdasarkan tabel di atas dapat diketahui bahwa dari keseluruhan aspek pada dimensi penilaian hasil belajar ternyata sebagian responden yaitu sebanyak $50 \%$ menyatakan mereka merasa puas terhadap kinerja dosen pada dimensi penilaian hasil belajar. Dan hanya 35\% dan 15\% saja yang menyatakan sangat puas dan cukup puas terhadap kinerja dosen pada dimensi penilaian hasil belajar. Hal ini berarti bahwa kesediaan dosen membantu mahasiswa, memberikan perhatian terhadap kemajuan mahasiswa, dan memberikan motivasi/masukan/pujian kepada mahasiswa, telah terlaksana dengan baik, namun demikian kepada dosen Program Studi Pendidikan Akuntansi masih perlu ditingkatkan yang berkaitan dengan aspek di atas.

\section{Penutup}

Penutup, yaitu kegiatan membuat rangkuman materi pembelajaran dengan melibatkan mahasiswa yang dilaksanakan di akhir proses pembelajaran. Indikator penilaiannya meliputi membuat rangkuman pembelajaran dengan melibatkan mahasiswa.

Berdasarkan hasil penelitian pada mahasiswa pendidikan akuntansi angkatan 2015 dapat dilihat distribusi frekuensi kepuasan mahasiswa pendidikan akuntansi terhadap kinerja dosen pada aspek penutup. 
Tabel 7. Distribusi frekuensi kepuasan mahasiswa terhadap kinerja dosen pada aspek penutup

\begin{tabular}{|c|c|c|c|c|c|c|c|}
\hline \multirow{2}{*}{ No } & \multirow{2}{*}{ Pernyataan } & \multicolumn{5}{|c|}{ Persentase Nilai yang Dicapai (\%) } & \multirow{2}{*}{$\begin{array}{l}\mathrm{Jml} \\
(\%)\end{array}$} \\
\hline & & SP & $\mathbf{P}$ & $\mathbf{C P}$ & $\mathbf{K P}$ & $\mathbf{T P}$ & \\
\hline $\mathbf{G}$ & Penutup & & & & & & \\
\hline 1 & $\begin{array}{l}\text { Membuat rangkuman } \\
\text { pembelajaran dengan } \\
\text { melibatkan mahasiswa }\end{array}$ & 5 & 35 & 60 & $\mathbf{0}$ & $\mathbf{0}$ & 100 \\
\hline
\end{tabular}

\section{Keterangan:}

$\begin{array}{llllll}\text { SP } & \text { : Sangat Puas, } & \text { P } & \text { : Puas, } & \text { CP } & \text { : Cukup Puas, } \\ \text { KP } & \text { : Kurang Puas, } & \text { TP } & \text { : Tidak puas } & & \end{array}$

Berdasarkan tabel di atas dapat diketahui bahwa dari keseluruhan aspek pada dimensi penutup ternyata sebagian responden yaitu sebanyak $60 \%$ menyatakan mereka merasa cukup puas terhadap kinerja dosen pada dimensi penutup. Dan hanya 35\% dan 5\% saja yang menyatakan puas dan sangat puas terhadap kinerja dosen pada dimensi penutup. Hal ini berarti bahwa kemampuan dosen membuat rangkuman materi pembelajaran dengan melibatkan mahasiswa, telah terlaksana dengan cukup baik, namun demikian kepada dosen Program Studi Pendidikan Akuntansi masih perlu ditingkatkan yang berkaitan dengan aspek di atas.

\section{Pembahasan}

Berdasarkan hasil analisis tingkat kepuasan mahasiswa terhadap kinerja dosen pada Program Studi Pendidikan Akuntansi FKIP Universitas Galuh Ciamis. Secara keseluruhan pada dimensi Performance (penampilan), tingkat kepuasan mahasiswa sudah dikategorikan puas. Hal ini dapat dilihat dari aspek dosen yang berpakaian sopan dan berpenampilan menarik sebesar $50 \%$, aspek dosen bersikap baik dan profesional sebesar $45 \%$.

Pada dimensi penguasaan materi perkuliahan, tingkat kepuasan mahasiswa sudah dikategorikan puas. hal ini bisa dilihat dari aspek dosen mampu menguasai materi dan keterkaitan dengan realita kehidupan sebesar $60 \%$, aspek dosen menggunakan komunikasi interaktif pada perkuliahan sebesar $70 \%$, aspek dosen menggunakan unsur-unsur kebahasaan sebesar $60 \%$, aspek dosen menggunakan struktur logika sebesar $70 \%$.

Pada dimensi proses pembelajaran, tingkat kepuasan mahasiswa sudah dikategorikan puas. Hal ini dapat dilihat dari aspek dosen melaksanakan pembelajaran sesuai SAP sebesar $65 \%$, aspek dosen melaksanakan pembelajaran yang sesuai dengan tingkat perkembangan sebesar 50\%, aspek dosen melaksanakan pembelajaran yang memungkinkan tumbuhnya kebiasaan positif sebesar $40 \%$, aspek dosen mampu menguasai kelas sebesar 45\%, aspek dosen melaksanakan pembelajaran tepat waktu sesuai jadwal sebesar $40 \%$, aspek dosen melaksanakan pembelajaran sesuai waktu yang telah dialokasikan sebesar $50 \%$.

Pada dimensi penggunaan media pembelajaran, tingkat kepuasan mahasiswa sudah dikategorikan puas. Hal ini bisa dilihat dari aspek keterampilan dosen dalam menggunakan media pembelajaran sebesar $75 \%$, aspek keterlibatan mahasiswa dalam menggunakan media pembelajaran sebesar $45 \%$.

Pada dimensi pembelajaran dengan keterlibatan mahasiswa, tingkat kepuasan mahasiswa sudah dikategorikan puas. Hal ini dapat dilihat dari aspek dosen menumbuhkan partisipasi aktif mahasiswa sebesar $65 \%$, aspek memfasilitasi interaksi dosen-mahasiswa sebesar 60\%, aspek dosen memfasilitasi interaksi terhadap mahasiswa-mahasiswa sebesar $65 \%$, aspek dosen bersikap terbuka terhadap partisipasi aktif mahasiswa sebesar $60 \%$.

Pada dimensi penilaian hasil belajar, tingkat kepuasan mahasiswa sudah dikategorikan puas. Hal ini dapat dilihat dari aspek penilaian hasil belajar mahasiswa sebesar $50 \%$.

Pada dimensi penutup, tingkat kepuasan mahasiswa dikategorikan cukup puas. Hal ini dapat dilihat dari aspek dosen mampu membuat 
rangkuman materi pembelajaran dengan melibatkan mahasiswa sebesar $60 \%$.

\section{PENUTUP \\ Simpulan}

Berdasarkan hasil penelitian dan pembahasan yang telah dilakukan dapat disimpulkan sebagai berikut:

1. Tingkat kepuasan mahasiswa Pendidikan Akuntansi terhadap kinerja dosen dalam pembelajaran yang ditinjau dari dimensi performance (penampilan) adalah sebagian besar responden $47,5 \%$ menyatakan puas terhadap semua aspek pada dimensi ini.

2. Tingkat kepuasan mahasiswa Pendidikan Akuntansi terhadap kinerja dosen dalam pembelajaran yang ditinjau dari dimensi penguasaan materi perkuliahan adalah sebagian besar responden $65 \%$ menyatakan puas terhadap semua aspek pada dimensi ini.

3. Tingkat kepuasan mahasiswa Pendidikan Akuntansi terhadap kinerja dosen dalam pembelajaran yang ditinjau dari dimensi proses pembelajaran adalah sebagian besar responden $48,33 \%$ menyatakan puas terhadap semua aspek ini.

4. Tingkat kepuasan mahasiswa Pendidikan Akuntansi terhadap kinerja dosen dalam pembelajaran yang ditinjau dari dimensi penggunaan media pembelajaran adalah sebagian besar responden $60 \%$ menyatakan puas terhadap semua aspek ini.

5. Tingkat kepuasan mahasiswa Pendidikan Akuntani terhadap kinerja dosen dalam pembelajaran yang ditinjau dari dimensi pembelajaran dengan keterlibatan mahasiswa adalah sebagian besar responden 62,5\% menyatakan puas terhadap semua aspek ini.

6. Tingkat kepuasan mahasiswa Pendidikan Akuntani terhadap kinerja dosen dalam pembelajaran yang ditinjau dari dimensi penilaian hasil belajar mahasiswa adalah sebagian besar responden 50\% menyatakan puas terhadap semua aspek ini.

7. Tingkat kepuasan mahasiswa Pendidikan Akuntani terhadap kinerja dosen dalam pembelajaran yang ditinjau dari dimensi penutup adalah sebagian besar responden $60 \%$ menyatakan cukup puas terhadap semua aspek ini.

\section{Saran}

Berdasarkan hasil penelitian dan pembahasan yang telah dikemukakan, maka penulis menyampaikan saran sebagai berikut:
1. Dari dimensi performance (penampilan) diharapkan dosen dapat berpakaian lebih sopan, berpenampilan menarik dan meyakinkan serta bersikap lebih baik dan profesional pada saat proses perkuliahan.

2. Dari dimensi penguasaan materi perkuliahan diharapkan dosen dapat lebih menggunakan komunikasi interaktif pada saat proses perkuliahan.

3. Dari dimensi proses pembelajaran diharapkan dosen dapat melaksanakan pembelajaran sesuai dengan SAP, melaksanakan pembelajaran yang sesuai dengan tingkat perkembangan, melaksanakan pembelajaran tepat waktu sesuai dengan jadwal yang telah ditetapkan serta sesuai dengan waktu yang telah dialokasikan.

4. Dari dimensi penggunaan media pembelajaran diharapkan dosen dapat lebih kreatif dalam penggunaan media pembelajaran dan dapat melibatkan mahasiswa dalam penggunaan media pembelajaran.

5. Dari dimensi pembelajaran dengan keterlibatan mahasiswa diharapkan dosen dapat menumbuhkan partisipasi aktif mahasiswa, memfasilitasi interaksi dosenmahasiswa, memfasilitasi interaksi mahasiswa-mahasiswa dalam proses perkuliahan.

6. Dari dimensi penilaian hasil belajar mahasiswa diharapkan dosen dapat melaksanakan penilaian akhir sebagai evaluasi akhir proses pembelajaran yang dilakukan secara obyektif dalam proses perkuliahan.

7. Dari dimensi penutup diharapkan dosen dapat membuat rangkuman materi pembelajaran dengan melibatkan mahasiswa dalam proses perkuliahan.

\section{DAFTAR PUSTAKA}

Kotler, Philip, 2000, Marketing Management, Prentice Hall.Inc Mardalis, 2006. Metodologi Penelitian Suatu Pendekatan Proposal. PT Bumi Aksara: Jakarta

Rivai, Veithzal, 2005. Performance appraisal (sistem yang tepat untuk menilai kinerja karyawan dan meningkatkan daya saing perusahaan).PT. Raja Grafindo Persada, Jakarta

Tjiptono, Fandy, 2004. Manajemen Jasa. Edisi ketiga. PT Andi: Yogyakarta 
